\title{
UJI AKTIVITAS ANTIOKSIDAN EKSTRAK ETANOL ASCIDIAN Herdmania Momus DENGAN METODE DPPH (1,1-difenil-2-pikrilhidrazil)
}

\section{ANTIOXIDANT ACTIVITY TEST OF ETHANOL EXTRACTS OF ASCIDIAN Herdmania momus USING DPPH METHOD (1,1-diphenyl-2-picrylhydrazyl)}

\author{
Frelinsia V.M Damanis ${ }^{1)}$, Defny S Wewengkang ${ }^{1)}$, Irma Antasionasti ${ }^{1)}$ \\ ${ }^{1)}$ Program Studi Farmasi FMIPA UNSRAT Manado, 95115 \\ *damanisv@gmail.com
}

\begin{abstract}
Ascidian Herdmania momus is one of the components of coral reef biota that has bioactive potential. Bioactive compounds function as self-defense and also function for human life, one of which can be used as a source of antioxidants. The purpose of this study is to determine the antioxidant activity from the ethanol extracts of the Ascidian Herdmania momus. Ascidian Herdmania momus was extracted using maceration method with ethanol as a solvent. As a parameter, testing of antioxidant activity was carried out by the DPPH (1,1-diphenil-2picrylhydarzyl) method measured using $U V$-Vis spectrophotometry with variations in concentrations of $25,50,75,100$, and $125 \mu \mathrm{g} / \mathrm{mL}$. The results of the average \% inhibition values obtained were 59.13\% (25 $\mathrm{g} / \mathrm{mL}), 60.93 \%(50 \mu \mathrm{g} / \mathrm{mL}), 61.73 \%(75 \mu \mathrm{g} / \mathrm{mL}), 63.86 \%(100 \mu \mathrm{g} /$ $\mathrm{mL})$ and $66.16 \%(125 \mu \mathrm{g} / \mathrm{mL})$. The highest antioxidant activity was found at a concentration of $125 \mu \mathrm{g} / \mathrm{mL}$ with an average \% inhibition value of $66.16 \%$. The conclusion is the ethanol extracts of Ascidian Herdmania momus was shown to have antioxidant activity in each concentration of the test.
\end{abstract}

Keywords: Ascidian Herdmania momus, Antioxidants, Extraction, DPPH

\begin{abstract}
ABSTRAK
Ascidian Herdmania momus merupakan salah satu komponen biota penyusun terumbu karang yang mempunyai potensi bioaktif. Senyawa bioaktifnya berfungsi sebagai pertahanan diri dan juga berfungsi bagi kehidupan manusia, salah satunya dapat dijadikan sebagai sumber antioksidan. Tujuan dari penelitian ini yaitu, untuk mengetahui aktivitas senyawa antioksidan dari ekstrak etanol Ascidian Herdmania momus. Ascidian Herdmania momus diekstraksi menggunakan metode maserasi dengan etanol sebagai pelarut. Sebagai parameter, pengujian aktivitas antioksidan dilakukan dengan metode DPPH (1,1-diphenil-2-picrylhydarzyl) yang diukur menggunakan Spektrofotometri UV-Vis dengan variasi konsentrasi $25,50,75,100$, dan $125 \mu \mathrm{g} / \mathrm{mL}$. Hasil nilai $\%$ inhibisi rata-rata yang didapat yaitu 59.13\% $(25 \mu \mathrm{g} / \mathrm{mL}), 60.93 \%(50 \mu \mathrm{g} / \mathrm{mL}), 61.73 \%(75 \mu \mathrm{g} / \mathrm{mL})$, $63.86 \%(100 \mu \mathrm{g} / \mathrm{mL})$ dan $66.16 \%(125 \mu \mathrm{g} / \mathrm{mL})$. Aktivitas antioksidan tertinggi terdapat pada konsentrasi $125 \mu \mathrm{g} / \mathrm{mL}$ dengan nilai \% inhibisi rata-rata $66.16 \%$. Kesimpulan yang didapat yaitu ekstrak etanol Ascidian Herdmania momus terbukti memiliki aktivitas antioksidan disetiap konsentrasi pengujian.
\end{abstract}

Kata Kunci : Ascidian Herdmania momus, Antioksidan, Ekstraksi, DPPH 


\section{PENDAHULUAN}

Ascidian merupakan salah satu komponen biota penyusun terumbu karang yang mempunyai potensi bioaktif, sehingga menjadikan ascidian target yang sangat menar ik karena keanekaragamannya yang tinggi dan unik diantara avertebrata laut karena menghas ilkan sejumlah besar senyawa yang mengandu ng nitrogen (Wang and Namikoshi, 2007). Senyawa bioaktif ascidian berfungsi sebagai pertahanan diri dan juga berfungsi bagi kehidupan manusia, yaitu sebagai antikanker, antiinflamasi, antimikroba dan antioksidan (Khoeri, 2009).

Antioksidan atau senyawa penangkal radikal bebas merupakan zat yang dapat menetralkan radikal bebas, atau suatu bahan yang berfungsi mencegah sistem biologi tubuh dari efek yang merugikan yang timbul dari proses ataupun reaksi yang menyebabkan oksidasi yang berlebihan. Berbagai bukti ilmiah menunjukkan bahwa senyawa antioksi dan mengurangi resiko terhadap penyakit kro nis seperti kanker dan penyakit jantung koron er (Prakash, 2001). Radikal bebas merupakan salah satu bentuk senyawa reaktif, yang secara umum diketahui sebagai senyawa yang memiliki elektron yang tidak berpasangan di kulit terluarnya. Elektron yang tidak memiliki pasangan cenderung akan menarik elektron dari senyawa lain, sehingga elektron tersebut akan dimiliki bersama oleh dua atom atau senyawa dan terbentuk suatu senyawa radikal bebas yang baru yang lebih reaktif (Uppu, et al., 2010). Antioksidan bekerja dengan cara mendonorkan satu elektronnya kepada senyawa yang besifat oksidan sehingga aktivitas senyawa oksidan tersebut bias terhambat. Antioksidan menstabilkan radikal bebas dengan melengkapi kekurangan elektron yang dimiliki radikal bebas dan menghambat terjadinya reaksi berantai dari pembentukan radikal bebas (Winarsi, 2007).

Herdmania momus merupakan jenis tunikata yang soliter, dan jarang keberadaann ya, bentuk tubuhnya bulat berkisar antara 50$100 \mathrm{~mm}$. Jenis ini sangat rentan jika disentuh dan biasanya berwarna 29 merah dengan perpaduan putih (Hakim, 2014).
Pada penelitian ini dilakukan uji aktivitas antioksidan ekstrak etanol ascidian Herdmania momus yang diambil dari Perairan Pulau Bangka Likupang dengan metode DPPH (1,1-diphenyl-2-picrylhidrazil).

\section{METODOLOGI PENELITIAN Waktu dan Tempat Penelitian}

Penelitian ini dilaksanakan pada bulan November 2019 - Juli 2020 di laboratorium penelitian lanjutan Program studi Farmasi, Fakultas Matematika dan Ilmu Pengetahuan Alam, Universitas Sam Ratulangi.

\section{Bentuk Penelitian}

Bentuk penelitian yaitu eksperimen laboratorium dengan rancangan penelitian dimana sampel ascidian Herdmania momus disiapkan dan diekstraksi dengan metode maserasi menggunakan pelarut etanol kemudian dilakukan uji aktivitas antioksidan terhadap DPPH (1,1-diphenil-2-picrylhydarz $y l)$.

\section{Alat dan Bahan}

Alat

Alat-alat yang digunakan pada penelitian ini yaitu peralatan scuba diving, kamera, gunting, pisau, wadah botol air kemasan $600 \mathrm{~mL}$, ziplok, sarung tangan, telenan, kertas saring, aluminium foil, tissue, kertas label, cawan petri, gelas ukur, erlenmeyer, tabung reaksi, baker glass, vortex, corong, pipet, mikro pipet, timbangan digital, spatula, oven, spektrofotometer UVVis.

\section{Bahan}

Bahan-bahan yang digunakan pada penelitian ini yaitu Ascidian Herdmania momus, etanol 96\%, serbuk Vitamin C p.a dan serbuk DPPH (1,1-diphenil-2-picrylhydra $z y l)$.

\section{Prosedur Penelitian \\ Pengambilan dan Preparasi Sampel}

Sampel ascidian Herdmania momus diperoleh dari perairan Pulau Bangka Likupang Kabupaten Minahasa Utara. Sampel diambil dengan menggunakan alat bantu 
(peralatan scuba diving, ziplok dan pisau), kemudian dimasukkan dalam ziplok dan diberikan label. Sampel yang telah didapat langsung dibersihkan dari pengotor, lalu dipotong kecil-kecil dan langsung dimasukkan kedalam botol yang berisi pelarut etanol 96\%, dan dimasukkan kedalam cool box

\section{Ekstraksi dengan Metode Maserasi}

Sampel direndam dengan mengguna kan larutan etanol 96\%. Metode ekstraksi dilakukan dengan cara merendam sampel dengan larutan penyari selama 3 kali 24 jam pada temperatur kamar yang dilindungi dari cahaya dan sesekali dikocok. Kemudian diambil filtratnya dan residu dibuang dan menghasilkan 3 filtrat yang kemudian dicampur menjadi satu. Filtrat tersebut dipekatkan dengan menggunakan oven pada suhu $40^{\circ} \mathrm{C}$ sampai etanol menguap.

\section{Pembuatan Larutan Stok}

Sebanyak $100 \mathrm{mg}$ ekstrak etanol ascidian Herdmania momus dilarutkan didalam etanol $96 \%$ ad. $100 \mathrm{~mL}$ (konsentrasi $1000 \mathrm{ppm})$. Dengan masing-masing konsent rasi $125 \mu \mathrm{g} / \mathrm{mL}, 100 \mu \mathrm{g} / \mathrm{mL}, 75 \mu \mathrm{g} / \mathrm{L}, 50$ $\mu \mathrm{g} / \mathrm{mL}$, dan $25 \mu \mathrm{g} / \mathrm{mL}$ dihitung dengan menggunakan rumus pengenceran, yaitu :

$$
M_{1} \times V_{1}=M_{2} \times V_{2}
$$

Pada kelima konsentrasi, masingmasing hasil yang didapatkan dari hasil $\mathrm{V}_{1}$ dipipet dan ditambahkan etanol 96\% hingga mencapai tanda batas $(10 \mathrm{~mL})$, kemudian dipindahkan ke dalam tabung reaksi dan ditutup dengan menggunakan aluminium foil untuk digunakan pada perlakuan selanjutnya.

\section{Pembuatan dan Pengujian Larutan Kontrol DPPH}

Sebanyak 4 mg serbuk DPPH ditimbang dan dilarutkan dalam etanol $96 \%$ sebanyak $100 \mathrm{~mL}$. Selanjutnya larutan stok DPPH dilakukan pengujian kontrol, dengan diukur serapannya menggunakan spektrofoto meter UV-Vis pada panjang gelombang maksimum yaitu $517 \mathrm{~nm}$.

Pengujian Aktivitas Antioksidan Esktrak dengan Metode DPPH

Sebanyak $2 \mathrm{~mL}$ ekstrak etanol Ascidian Herdmania momus dengan konsentrasi $125 \mu \mathrm{g} / \mathrm{mL}, 100 \mu \mathrm{g} / \mathrm{mL}, 75$ $\mu \mathrm{g} / \mathrm{mL}, \quad 50 \mu \mathrm{g} / \mathrm{mL}$ dan $25 \mu \mathrm{g} / \mathrm{mL}$ ditambahkan masing-masing $2 \mathrm{~mL}$ larutan DPPH dalam etanol dan divorteks selama 5 detik. Berubahnya warna ungu menjadi warna kuning menunjukkan efisiensi penangkal radikal bebas. Diukur absorbansi pada spektrofotometer UV-Vis dengan panjang gelombang $517 \mathrm{~nm}$, setelah diinkubasi selama 30 menit. Kemudian diamati perbandingannya dengan vitamin $\mathrm{C}$ p.a sebagai standar.

\section{Pembuatan dan Pengujian Larutan Pembanding Vitamin C (p.a) \\ Larutan Vitamin C ditimbang} sebanyak $10 \mathrm{mg}$. Kemudian, vitamin C p.a dilarutkan dalam etanol $96 \%$ sebanyak 10 $\mathrm{mL}$, buat larutan stok dengan konsentrasi yang sama sebelumnya yaitu konsentrasi 125 $\mu \mathrm{g} / \mathrm{mL}, 100 \mu \mathrm{g} / \mathrm{mL}, 75 \mu \mathrm{g} / \mathrm{mL}, 50 \mu \mathrm{g} / \mathrm{mL}$ dan $25 \mu \mathrm{g} / \mathrm{mL}$ dengan ditambahkan masingmasing larutan dengan etanol p.a mencapai tanda batas $(10 \mathrm{~mL})$, dengan pengulangan sebanyak 3 kali pada masing-masing konsentrasi. Pada masing-masing konsentrasi di pipet $2 \mathrm{~mL}$ dan ditambahkan larutan DPPH $2 \mathrm{~mL}$, di vorteks selama 5 detik dan diinkubasi selama 30 menit pada suhu $37^{\circ} \mathrm{C}$. Sampel vitamin C p.a diuji pada spektrofotometer UV-Vis dengan panjang gelombang $517 \mathrm{~nm}$. Setelah absorbansi didapat, aktivitas penangkapan radikal bebas (persen inhibisi) dihitung sebagai persentase berkurangnya warna DPPH dengan menggunakan rumus berikut:

$$
\% \text { inhibisi }=1-\frac{\text { Absorbansi sampel }}{\text { Absorbansi kontrol }} \times 100 \%
$$

\section{Analisis Data}

Aktivitas antioksidan di ukur dengan menggunakan spektrovotometer UV-Vis, 
kemudian data yang diperoleh disajikan dalam bentuk tabel.

\section{HASIL DAN PEMBAHASAN Hasil}

Penelitian dilakukan pada ekstrak etanol Ascidian Herdmania momus untuk mengetahui adanya aktivitas dari penangkal radikal bebas yang di uji dengan menggunakan Spektrofotometer UV-Vis.

Data absorbansi sampel ekstrak etanol Ascidian Herdmania momus, Vitamin C (p.a) sebagai pembanding dan kontrol DPPH disajikan pada Tabel 1 dan Data \% inhibisi ekstrak etanol Ascidian Herdmania momus dan Vitamin C (p.a) sebagai pembanding disajikan pada Tabel 2 berikut ini :

Tabel 1. Data absorbansi sampel ekstrak etanol Ascidian Herdmania momus, Vitamin C (p.a) dan Kontrol DPPH

\begin{tabular}{|c|c|c|c|c|}
\hline \multirow{2}{*}{\multicolumn{2}{|c|}{$\begin{array}{c}\text { KONSENTRASI } \\
\text { Ekstrak dan Vitamin C }\end{array}$}} & \multicolumn{3}{|c|}{$\begin{array}{c}\text { ABSORBANSI } \\
\text { PENGULANGAN }\end{array}$} \\
\hline & & \multirow{2}{*}{$\frac{\mathrm{I}}{0.306}$} & \multirow{2}{*}{$\frac{\text { II }}{0.303}$} & \multirow{2}{*}{$\begin{array}{c}\text { III } \\
0.322\end{array}$} \\
\hline $25 \mu \mathrm{g} / \mathrm{mL}$ & Ekstrak & & & \\
\hline & Vit. C & 0.112 & 0.111 & 0.134 \\
\hline \multirow[t]{2}{*}{$50 \mu \mathrm{g} / \mathrm{mL}$} & Ekstrak & 0.296 & 0.284 & 0.310 \\
\hline & Vit. C & 0.108 & 0.104 & 0.110 \\
\hline \multirow[t]{2}{*}{$75 \mu \mathrm{g} / \mathrm{mL}$} & Ekstrak & 0.297 & 0.295 & 0.279 \\
\hline & Vit. C & 0.101 & 0.113 & 0.110 \\
\hline \multirow[t]{2}{*}{$100 \mu \mathrm{g} / \mathrm{mL}$} & Ekstrak & 0.267 & 0.293 & 0.263 \\
\hline & Vit. C & 0.110 & 0.111 & 0.106 \\
\hline \multirow[t]{2}{*}{$125 \mu \mathrm{g} / \mathrm{mL}$} & Ekstrak & 0.257 & 0.264 & 0.249 \\
\hline & Vit. C & 0.108 & 0.101 & 0.100 \\
\hline \multicolumn{2}{|c|}{ KONTROL DPPH } & & 0.728 & \\
\hline
\end{tabular}

Tabel 2. Hasil pengujian perbandingan Ekstrak Etanol Ascidian Herdmania momus dan Vitamin C (p.a).

\begin{tabular}{cccccc}
\hline \multirow{2}{*}{$\begin{array}{c}\text { KONSENTRASI } \\
\text { Ekstrak dan Vitamin C }\end{array}$} & \multicolumn{3}{c}{ PENGULANGAN } & \multirow{2}{*}{ RATA -RATA } \\
\cline { 2 - 5 } & Ekstrak & I & II & III & \\
\hline \multirow{2}{*}{$25 \mu \mathrm{g} / \mathrm{mL}$} & Vit. C & $85.70 \%$ & $60.10 \%$ & $57.60 \%$ & $59.13 \%$ \\
\cline { 2 - 5 } & Ekstrak & $61.0 \%$ & $62.60 \%$ & $59.20 \%$ & $64.36 \%$ \\
\cline { 2 - 5 } $50 \mu \mathrm{g} / \mathrm{mL}$ & Vit. C & $85.80 \%$ & $86.30 \%$ & $85.50 \%$ & $85.86 \%$ \\
& Ekstrak & $60.90 \%$ & $61.10 \%$ & $63.20 \%$ & $61.73 \%$ \\
\hline \multirow{2}{*}{$75 \mu \mathrm{g} / \mathrm{mL}$} & Vit. C & $86.70 \%$ & $85.10 \%$ & $85.50 \%$ & $85.76 \%$ \\
& Ekstrak & $64.80 \%$ & $61.40 \%$ & $65.40 \%$ & $63.86 \%$ \\
\hline \multirow{2}{*}{$100 \mu \mathrm{g} / \mathrm{mL}$} & Vit. C & $85.50 \%$ & $85.40 \%$ & $86.10 \%$ & $85.66 \%$ \\
\cline { 2 - 5 } & & & & &
\end{tabular}




\begin{tabular}{lccccc}
\hline \multirow{2}{*}{$125 \mu \mathrm{g} / \mathrm{mL}$} & Ekstrak & $66.10 \%$ & $65.20 \%$ & $67.20 \%$ & $66.16 \%$ \\
\cline { 2 - 5 } & Vit. C & $85.80 \%$ & $86.70 \%$ & $86.90 \%$ & $86.46 \%$ \\
\hline
\end{tabular}

\section{Pembahasan}

Pada Pada penelitian ini, Ascidian Herdmania momus digunakan sebagai sampel. Dilakukan Preparasi sampel, sampel dipotong kecil-kecil bertujuan untuk memperbesar ukuran permukaan sampel sehingga proses ekstraksi berjalan optimal karena semakin luas permukaan sampel maka interaksi antara pelarut dan sampel semakin besar (Mardiyah et al., 2014).

Sampel kemudian di ekstraksi menggunakan metode maserasi. Tujuan pemilihan metode maserasi karena cara pengerjaannya yang sederhana dan cepat namun sudah dapat menarik senyawa kimia dari sampel dengan maksimal. Keuntungan utama dari metode ini ialah tidak dilakukan pemanasan sehingga dapat mencegah kemungkinan terjadinya penguraian zat aktif yang terkandung di dalam sampel akibat pengaruh suhu dan senyawa yang tidak tahan pemanasan (Sa'adah et al., 2015). Agar senyawa kimia di dalam sampel dapat terekstrak secara menyeluruh maka dilakukan remaserasi atau pengulangan dengan penggantian pelarut sebanyak tiga kali. Pemilihan pelarut pada umumnya dipengaruhi oleh beberapa faktor antara lain selektivitas, kelarutan, dan titik didih. Pada penelitian ini, sampel Ascidan Herdmania momus diekstraksi menggunakan metode maserasi dan pelarut yang digunakan adalah etanol $96 \%$, alasan pemilihan etanol $96 \%$ sebagai pelarut dalam proses maserasi adalah karena lebih selektif, tidak toksik, absorbsinya baik dan dapat mencegah pertumbuhan bakteri dan jamur (Suryanto, 2012).

Konsentrasi ekstrak etanol Ascidian Herdmania momus yang digunakan adalah $125,100,75,50$, dan $25 \mu \mathrm{g} / \mathrm{mL}$. Masingmasing konsentrasi dicampurkan dengan larutan DPPH. Campuran dihomogenkan dan diinkubasi selama 30 menit pada tempat gelap dengan suhu $37^{\circ} \mathrm{C}$. Setelah sampel diinkubasi, kemudian masing-masing ekstrak dilakukan pengukuran absorbansi dengan menggunakan spektrofotometer UV-Vis pada panjang gelombang $517 \mathrm{~nm}$. Pada tiap konsentrasi dilakukan sebanyak 3 kali pengulangan. Pengukuran aktivitas antioksidan sampel dilakukan pada panjang gelombang $517 \mathrm{~nm}$ karena DPPH memberikan serapan yang kuat pada panjang gelombang tersebut.

Berdasarkan hasil yang diperoleh pada pengujian DPPH persen inhibisi pada ekstrak etanol Ascidian Herdmania momus dan Vitamin $\mathrm{C}$ disajikan pada Tabel 2 mengalami peningkatan dari konsentrasi terendah 25 $\mu \mathrm{g} / \mathrm{mL}$ yakni $59.13 \%$ sampai pada konsentrasi tertinggi $125 \mu \mathrm{g} / \mathrm{mL}$ dengan nilai rata-rata $66.16 \%$. Peningkatan persen inhibisi ini pada ekstrak menandakan bahwa semakin besar konsentrasi ekstrak maka semakin besar persen inhibisi. Hal ini didukung oleh penelitian yang dilakukan oleh Hanani et al., (2005) yang menyatakan bahwa presentase penghambatan (persen inhibisi) terhadap aktivitas radikal bebas akan ikut meningkat seiring dengan meningkatnya konsentrasi. Hasil pengujian perbandingan aktivitas antioksidan ekstrak etanol Ascidian Herdmania momus dan Vitamin $\mathrm{C}$ menun jukkan bahwa kemampuan penangkal radikal bebas dari Vitamin $\mathrm{C}$ lebih kuat dibandingkan dengan ekstrak etanol Ascidian Herdmania momus.

Pembanding yang digunakan sebagai kontrol positif adalah vitamin $\mathrm{C}$, digunakan sebagai pembanding karena berfungsi sebagai antioksidan sekunder yaitu menangkap radikal bebas, mencegah terjadinya reaksi berantai, aktivitas antioksidannya sangat tinggi, mudah diperoleh dan vitamin $\mathrm{C}$ lebih polar dari vitamin yang lain. Vitamin $\mathrm{C}$ mempunyai gugus hidroksi bebas yang bertindak sebagai penangkap radikal bebas (Isnindar, 2011). Hasil penelitian menunjukkan bahwa dengan bertambahnya konsentrasi ekstrak maka absorbansi sampel akan menurun dan tingkat inhibisi akan naik. Absorbansi sampel turun karena elektron pada DPPH menjadi berpasangan dengan elektron 
sampel yang mengakibatkan warna larutan berubah dari ungu pekat menjadi kuning bening. Kondisi ini sesuai dengan pernyataan Green (2004) bahwa nilai tingkat inhibisi meningkat seiring meningkatnya konsentrasi sampel dikarenakan semakin banyak senyawa antioksidan pada sampel yang dapat menangkal radikal bebas.

\section{KESIMPULAN}

Berdasarkan dari hasil penelitian yang telah dilakukan dapat disimpulkan bahwa ekstrak Ascidian Herdmania momus dari perairan Pulau Bangka Likupang, memiliki aktivitas antioksidan pada setiap konsentrasi dan aktivitas antioksidan tertinggi terdapat pada konsentrasi $125 \mu \mathrm{g} / \mathrm{mL}$ dengan nilai persen inhibisi rata-rata $66.16 \%$.

\section{SARAN}

Perlu dilakukan penelitian lebih lanjut untuk mengetahui senyawa aktif yang terkandung dalam ekstrak etanol Ascidian Herdmania momus dan pengujian aktivitas antioksidan dengan metode lain FC (FolinCiocalteu), FRAP (Ferric Reducing Antioxidant Power), RP (Reducing Power) PV (Peroxide Value), TBA (2-thiobarbituric acid) dan sebaiknya membandingkan hasilnya dengan penelitian ini.

\section{DAFTAR PUSTAKA}

Green, R.J. 2004. Antioxidant activity of peanut plant Tissues. North caroline state university departemen of food science, Raleigh.

Hakim, M.F.B.A. 2013. Distribusi dan Keanekaragaman Tunikata (Ascidiace a) Pada Kondisi Perairan yang Berb eda di Pulau Badi, Bone Batang dan Lae-Lae [Skripsi]. Universitas Hasanu ddin, Makassar.

Hanani E, Mun'im B, Sekarini R. 2005. Identifikasi Senyawa Antioksidan dalam spons Callispongia sp. dari Kepulauan Seribu. Jurnal Ilmu Kefarmasian. 2 (3) : 127-133.
Isnindar. 2011. Isolasi dan Identifikasi Senyawa Antioksidan Daun Kesemek (Diopyroskaki Thunb) dengan Metode DPPH. Majalah Obat Tradisional. 16 (3) : 157-164.

Khoeri, M. M. 2009. Bioprospeksi Bakteri Simbion pada Tunikata Didemnum molle dari Perairan Pulau Sambangan Karimunjawa Jepara. Universitas Dipoengoro, Semarang.

Mardiyah, U., Fasya, G. A. Fauziyah, B., dan Amalia, S. 2014. Ekstraksi Uji Aktivitas Antioksidan dan Identifikasi Golongan Senyawa Aktif Alga Merah Eucheuma spinosum dari Perairan Banyuwangi. Jurnal Achemy. 3 (1) : 42

Prakash, A., F. Rigelhof., and E. Miller. 2001. Antioxidant Activity: Medallion Laboratories. Analithycal Progress. 19(2) : 1-4.

Sa'adah, H., Nurhasnawati, H. 2015. Perbandingan Pelarut Etanol Dan Air Pada Pembuatan Ekstrak Umbi Bawang Tiwai (Eleutherine Americana Merr) Menggunakan Metode Maserasi. Jurnal Ilmiah Manuntung. 1(2) : 149-153.

Suryanto, E. 2012. Fitokimia Antioksidan. Putra Media Nusantara, Surabaya.

Uppu, R. M., S.N. Murthy., W.A. Pryor., and N.L. Parinandi. 2010. Free Radical and Antioxidant Protocols. Humana Press, New York.

Wang, W., and Namikoshi, M. 2007. Bioactive Nitrogenous Metabolites from Ascidians. Heterocycles. 74 : 5388.

Winarsih, H. 2007. Antioksidan Alami dan Radikal Bebas. Kanisius, Jogjakarta. 